\title{
PENGARUH REWARD DAN KEPUASAN KERJA \\ TERHADAP KOMITMEN ORGANISASI KEPALA MADRASAH IBTIDAIYAH SWASTA DI JAKARTA TIMUR
}

(2013)

\begin{abstract}
Muhamad Alwi *
Abstract. The objective of this research is to obtain information concerning effect of reward, and job satisfaction on organizational commitment. The research was carried out by means of survey in East Jakarta, involving 88 principal as respondents who are selected through simple random sampling. This research finding are (1) there is a direct effect reward on organizational commitment. (2) there is a direct effect of reward on job satisfaction. (3) there is a direct effect of job satisfaction on organizational commitment. Therefore, the variation of principal's performance are effected by the variation of reward, variation of job satisfaction, and others variation.
\end{abstract}

Keywords: Reward, job satisfaction and organizational commitment.

\section{PENDAHULUAN}

Kepala sekolah sebagai pimpinan tertinggi yang sangat berpengaruh dan menentukan kemajuan sekolah harus memiliki kemampuan administrasi, memiliki komitmen tinggi, dan luwes dalam melaksanakan tugasnya. Rendahnya komitmen mencerminkan kurangnya tanggung jawab seseorang dalam menjalankan tugasnya. Mempersoalkan komitmen sama dengan mempersoalkan tanggung jawab, dengan demikian, ukuran komitmen seorang pimpinan yang dalam hal ini adalah kepala sekolah adalah terkait dengan pendelegasian wewenang (empowerment).

Kepala sekolah/madrasah yang memiliki komitmen dan kompetensi tinggi mutlak dibutuhkan untuk meningkatkan dan membangun sekolah/madrasah yang berkualitas. Komitmen terhadap organisasi artinya lebih dari sekedar keanggotaan formal, karena meliputi sikap menyukai organisasi dan kesediaan untuk mengusahakan tingkat upaya yang tinggi bagi kepentingan organisasi demi pencapaian tujuan. Berdasarkan definisi ini, dalam komitmen organisasi tercakup unsur loyalitas terhadap organisasi, keterlibatan dalam pekerjaan, dan identifikasi terhadap nilai-nilai dan tujuan organisasi.

Komitmen kepala sekolah/madrasah terhadap organisasi bukanlah merupakan suatu hal yang terjadi secara sepihak. Dalam hal ini yayasan dan kepala madrasah harus secara bersama-sama menciptakan kondisi yang kondusif untuk mencapai komitmen yang dimaksud. Sebagai contoh: seorang kepala madrasah yang semula kurang memiliki komitmen, namun setelah bekerja ternyata selain ia mendapat imbalan sesuai dengan ketentuan yang berlaku ternyata didapati adanya hal-hal yang menarik dan memberinya kepuasan. Hal itu tentu akan memupuk berkembangnya komitmen kepala madrasah tersebut terhadap organisasi. Apalagi jika tersedia faktor-faktor yang dapat memberikan kesejahteraan hidup atau jaminan keamanan, misalnya ada koperasi, ada fasilitas transportasi, ada fasilitas yang mendukung kegiatan kerja maka dapat dipastikan ia dapat bekerja dengan penuh semangat, lebih produktif, dan efisien dalam menjalankan tugasnya. Sebaliknya jika iklim organisasi kerja dalam organisasi tersebut kurang menunjang, misalnya fasilitas kurang, hubungan kerja kurang harmonis,

\footnotetext{
* Kepala Madrasah pada Madrasah Ibtidaiyah Istiqlal Jakarta Pusat.
} 
jaminan sosial dan keamanan kurang, maka secara otomatis komitmen kepala madrasah terhadap organisasi menjadi semakin luntur atau bahkan mungkin ia cenderung menjelek-jelekkan tempat kerjanya. Hal ini tentu saja dapat menimbulkan berbagai gejolak seperti indisipliner kerja, korupsi, mogok kerja, unjuk rasa, pengunduran diri, terlibat tindakan kriminal dan sebagainya.

Kepala sekolah/madrasah sebagai pemegang otoritas dalam pelaksanaan pendidikan perlu memahami proses pendidikan di sekolah/madrasah serta menjalankan tugasnya dengan baik, sehingga proses penyelenggaraan pendidikan di sekolah/madrasah dapat berjalan sesuai dan sejalan dengan upaya-upaya pencapaian tujuan pendidikan secara efektif dan efisien. Maju mundurnya suatu sekolah/madrasah tidak terlepas dari peran kepala sekolah/madrasah, karena kepala sekolah/madrasah berperan sebagai kekuatan sentral yang menjadi kekuatan penggerak kehidupan sekolah/madrasah. Sebagaimana E. Mulyasa menyatakan bahwa, kepala sekolah harus mampu berperan sebagai leader, innovator, dan motivator di sekolahnya. Dengan demikian dalam paradigma baru manajemen pendidikan, kepala sekolah sedikitnya harus mampu berfungsi sebagai educator, manajer, administrator, supervisor, leader, innovator, motivator (EMASLIM).

Untuk mewujudkan sekolah/madrasah efektif dibutuhkan kepala sekolah/madrasah yang tidak hanya sebagai figur personifikasi sekolah/madrasah, tapi juga paham tentang tujuan pendidikan, punya visi masa depan serta mampu mengaktualisasikan seluruh potensi yang ada menjadi suatu kekuatan yang bersinergi guna mencapai tujuan pendidikan. Hal ini lebih dikuatkan pendapatnya James L. Gibson (2006:184), "commitment to an organization involves three attitudes: (1) a sense of identification with the organization's goals, (2) a feeling of involvement in organizational duites, and (3) a feeling of loyalty for the organization" (seseorang berkomitmen pada suatu organisasi manakala menunjukkan tiga sikap, yaitu; (1) perasaan mengenali tujuan organisasi, (2) keterlibatan tugas dalam organisasi, dan (3) kesetiaan dalam organisasi).

Berdasarkan pengalaman dan perbincangan peneliti dengan sebagian kepala madrasah ibtidaiyah swasta di Jakarta Timur, didapat informasi tentang beberapa hal yang terkait dengan komitmen kepala madrasah, di antaranya adanya intervensi pelaksanaan tugas yang terlalu jauh dari pihak yayasan, kurangnya perhatian dan penghargaan terhadap apa yang telah dilakukan oleh kepala madrasah.

\section{Komitmen Organisasi}

Upaya peningkatan mutu pendidikan adalah menjadi tanggungjawab bersama, baik pemerintah, yayasan (sekolah/madrasah swasta), pengawas, pendidik, orangtua, maupun kepala sekolah/madrasah sebagai penggerak dari suatu lembaga pendidikan. Keterlibatan kepala sekolah/madrasah secara totalitas, loyalitas dan keyakinan untuk tetap bertahan dalam organisasi adalah mutlak dibutuhkan oleh lembaga pendidikan dalam upaya peningkatan mutu pendidikan. Oleh karena itu, berikut ini akan dijelaskan definisi komitmen organisasi dan hal-hal yang berkaitan dengan komitmen seorang kepala sekolah/madrasah dalam melaksanakan tugasnya. Sebagaimana pernyataan Richard L. Daft (2010:445), "organizational commitment is loyalty to and heavy involvement in one's organization." (Komitmen organisasi adalah loyalitas seseorang terhadap keterlibatan yang sangat kuat dalam sebuah organisasi). Definisi ini senada dengan pernyataan Gary Dessler (2001:472) yang menjelaskan, "commitment the relative strength of an individual's identification with and involvement in an organization." (Komitmen kekuatan relatif dari identifikasi individu dengan dan keterlibatan dalam organisasi). Selanjutnya, Ricky W. Griffin and Gregory (2007:71) menjelaskan, “organizational 
commitment is a person's identification with and attachment to an organization." (Komitmen organisasi adalah identifikasi seseorang dengan dan keterikatan pada organisasi).

Penjelasan lain menurut John R Schermerhorn (2010:335) menjelaskan, "organizational commitment is the loyalty of an individual to the organization." (Komitmen organisasi adalah loyalitas individu terhadap organisasi). Sedangkan menurut Debra L. Nelson and James Campbell Quick (2006:124) menjelaskan, "organizational commitment the strength of an individual's identification with an organization." (Komitmen organisasi kekuatan identifikasi individu dengan organisasi). Lebih lanjut Jennifer M. George and Gareth R. Jones (2005:75) menjelaskan, "organizational commitment is the collection of feeling and beliefs that people have about their organization as a whole." (Komitmen organisasi adalah kumpulan perasaan dan keyakinan bahwa orang miliki tentang organisasinya secara keseluruhan).

Selanjutnya Stephen P. Robbins and Timothi A. Judge (2011:111) menjelaskan, "there are three separate dimensions to organizational commitment; (1) affective commitment is an emotional attachment to the organizational and a belief its values. (2) Continuance commitment is the perceived economic value of remaining with an organization. (3) Normative commitment is an obligation to remain with the organization for moral or ethical reasons." (Ada tiga dimensi yang terpisah untuk komitmen organisasi; (1) komitmen afektif adalah keterikatan emosional dengan organisasi dan keyakinan nilai-nilainya. (2) komitmen Kesinambungan adalah nilai ekonomi yang dirasakan dari yang tersisa dengan sebuah organisasi. (3) komitmen normatif adalah kewajiban untuk tetap dengan organisasi karena alasan moral atau etika). Hal yang senada juga dijelaskan oleh pendapatnya Fred Luthans (2008:148) terkait dengan dimensi komitmen organisasi yang terdiri dari tiga macam dimensi yaitu, (1) komitmen afektif (2) komitmen kelanjutan dan (3) komitmen normatif. Adapun secara teoritis adalah sebagai berikut: (1) Affective commitment involves the employee's attachment to, identification with, and involvement in the organization, (2) Continuance commitment involves commitment based on the costs that the employee associates with leaving the organization. This may be because of the loss of senority for promotion or benefits, (3) Normative commitment involves employees' feelings of obligation to stay with the organization because they should; it is right thing to do.

Debra L. Nelson and James Campbell Quick (2006:124) juga sependapat dengan pernyataan Stephen P. Robbins and Timothi A dan Fred Luthans yang menyatakan bahwa dimensi komitmen organisasi terdiri dari tiga macam: There are three kinds of organizational commitment: affective, continuance, and normative. (1) Affective commitment is an employee's intention to remain in an organization because of a strong desire to do so. It consists of three factors: (a) A belief in the goals and values of the organization, (b) A willingness to put forth effort on behalf of the organization, (c) A desire to remain a member of the organization, (2) Continuance commitment is an employee's tendency to remain in an organization because the person cannot afford to leave, (3) Normative commitment is a perceived obligation to remain with the organization. (Ada tiga jenis komitmen organisasi: afektif, kelanjutan, dan normatif. (1) Komitmen afektif adalah niat karyawan untuk tetap dalam sebuah organisasi dikarenakan keinginan yang kuat untuk melakukannya. Ini terdiri dari tiga faktor: (a) Sebuah keyakinan akan tujuan dan nilai-nilai organisasi, (b) Keinginan untuk melahirkan upaya atas nama organisasi, (c) Keinginan untuk tetap menjadi anggota organisasi. (2) Komitmen kelanjutan kecenderungan karyawan untuk tetap dalam sebuah organisasi karena seseorang tidak mampu untuk pergi. (3) Komitmen normatif merupakan kewajiban dianggap tetap bersama organisasi).

Berdasarkan pemaparan di atas dapat disintesiskan bahwa komitmen organisasi adalah loyalitas, keyakinan, keterlibatan dan keinginan yang kuat untuk tetap konsisten 
bertahan dalam sebuah organisasi, dengan indikator: komitmen afektif (kenyakinan yang kuat terhadap nilai-nilai sebuah organisasi), komitmen kesinambungan atau kelanjutan (kecenderungan untuk tetap bertahan dalam sebuah organisasi), komitmen normatif (kewajiban moral untuk tetap konsisten dalam sebuah organisasi).

\section{Reward}

Reward menurut Fred Luthans (2008:382), "a rewards is simply something that the person who present it deems to be desirable." (Reward adalah sesuatu yang diharapkan dapat diterima sesuai dengan yang dikehendaki). Selanjutnya Richard L. Daft (2010:506), menambahkan apa yang definisikan oleh Fred Luthans bahwa, "the reward also informs the person that the behavior was appropriate and can be used again in the future." (Penghargaan juga menginformasikan seseorang bahwa perilaku sudah sesuai dan dapat digunakan lagi di masa depan). Lebih jelasnya Stephen P. Robbins and Timothi A. Judge (2011:486) menyatakan, "these rewards can be either financial-such as controlling pay rates, raises, and bonuses; or nonfinancial-including recognition, promotion, interesting work assignments, friendly colleagues, and preferred work shifts or sales territories." (Penghargaan ini dapat berupa keuangan-seperti mengontrol tingkat upah, kenaikan gaji, dan bonus, atau non finansial termasuk pengakuan, promosi, tugas pekerjaan yang menarik, rekan ramah, dan shift kerja yang lebih disukai atau sales teritori).

Selanjutnya Kinichi and Robert Kreitner (2008:208) menjelaskan bahwa, "rewards are an ever-present and always controversial feature of organizational life." (Penghargaan adalah fitur yang selalu ada dan selalu kontroversial dari kehidupan organisasi). Rae Andre (2008:108) menjelaskan bahwa, "rewards, a desired cosequence which is typically given for general performance, rather than being contingent on specific behavior." (Reward berkaitan dengan target perilaku kerja yang harus ditampilkan maka reward baru diberikan ketika kinerja telah dipenuhi sesuai dengan yang diharapkan).

Penjelasan lain yang menyatakan tentang reward sebagaimana James L. Gibson (2006:177) menjelaskan, "the main objectives of reward programs are (1) to attact qualified people to join the organization, (2) to keep employees coming to work, and (3) to motivate employees to achieve high levels of performance." (Sasaran utama program reward adalah (1) untuk menarik seseorang bergabung dalam organisasi (2) menerima pekerja datang untuk bekerja, dan (3) memotivasi pekerja untuk mencapai prestasi pada level/tingkat yang lebih tinggi). Sistem penghargaan yang baik menurut Angelo kinicki and Robert Kreither (2008:208) adalah: A good reward system should attract talented people and motivate and satisfy them once they have joined the organization. Further, a good reward system should foster personal growth and development and keep talented people from leaving. (Sistem penghargaan yang baik harus dapat menarik orang berbakat dan memotivasi dan memuaskan bagi mereka yang telah bergabung dengan organisasi. Selanjutnya, sistem upah yang baik harus mendorong pertumbuhan pribadi dan pengembangan dan mencegah orang berpotensi untuk meninggalkannya).

Kinicki juga menambahkan: "despite the fact that reward systems vary widely, it is possible to identify and interrelate some common components. Key factors in organizational rewards systems. three important components: (1) types of rewards, (2) distribution criteria, and (3) desired outcomes." Terlepas dari kenyataan bahwa sistem penghargaan sangat bervariasi, adalah mungkin untuk mengidentifikasi dan saling berhubungan beberapa komponen umum. Kunci faktor dalam sistem imbalan organisasi. tiga komponen penting: (1) jenis manfaat, (2) Kriteria distribusi, dan (3) hasil yang diinginkan. Kunci faktor dalam sistem penghargaan organisasi ada tiga komponen penting: (1) Jenis penghargaan - Keuangan / materi (ekstrinsik) - Hiburan (ekstrinsik) - Psikis (intrinsik) 
(2) Kriteria distribusi - Hasil - Perilaku - Faktor-faktor lain, dan (3) Hasil yang diinginkan - Menarik - Memotivasi - Mengembangkan - Memuaskan - Mempertahankan.

Selanjutnya James L. Gibson (2006:177) menjelaskan bahwa reward dapat dibagi dalam dua kategori, yaitu: "Classifies rewards into two broad categories; extrinsic and intrinsic. Extrintic rewards are rewards exsternal to the job, such as pay, promotion, or fringe benefits; Intrinsic rewards are those that are part of the job itself, such as the responsibility, challenge, and feedback characteristics of the job." Mengklasifikasikan penghargaan menjadi dua kategori besar; ekstrinsik dan intrinsik. penghargaan ekstrinsik adalah penghargaan exsternal dengan pekerjaan, seperti gaji, promosi, atau tunjangan; penghargaan intrinsik adalah mereka yang merupakan bagian dari pekerjaan itu sendiri, seperti tanggung jawab, tantangan, dan karakteristik umpan balik pekerjaan.

Hal ini senada dengan Richard L. Daft (2010:506) menjelaskan bahwa: "Rewards are of two types: intrinsic and extrinsic. Intrinsic rewards are the satisfactions a person receives in the process of performing a particular action. extrinsic rewards are given by another person, typically a manager, and include promotions, pay increases, and bonuses." Penghargaan terdiri dari dua jenis: intrinsik dan ekstrinsik. Imbalan intrinsik adalah kepuasan seseorang yang diterima dalam proses melakukan tindakan. imbalan ekstrinsik diberikan oleh orang lain, biasanya manajer, dan termasuk promosi, kenaikan gaji, dan bonus.

Begitu juga Kinichi (2008:209) menjelaskan bahwa: “An alternative typology for organizational rewards is the distinction between extrinsic and intrinsic rewards. Financial, material, and social rewards qualify as extrinsic rewards because they come from the environment. Psychic rewards, however, are intrinsic rewards because they are self-granted." Jenis penghargaan ekstrinsik dan penghargaan intrinsik. Imbalan keuangan, material, dan sosial memenuhi syarat sebagai imbalan ekstrinsik karena mereka datang dari lingkungan. Imbalan psikis, bagaimanapun, adalah imbalan intrinsik karena mereka adalah diri begitu saja.

Berdasarkan pemaparan di atas dapat disintesiskan bahwa reward adalah sesuatu yang diberikan ketika kinerja telah dipenuhi sesuai dengan yang diharapkan yang bertujuan untuk menarik seseorang bergabung dalam organisasi dan memotivasi seseorang untuk mencapai prestasi pada level/tingkat yang lebih tinggi, dengan indikator kenaikan gaji, pemberian bonus, pemberian tunjangan, promosi, dan tanggung jawab pada pekerjaan.

\section{METODE}

\section{Variabel Penelitian}

Metode yang digunakan adalah metode survei dengan unit analisis penelitian adalah kepala madrasah ibtidaiyah swasta di Jakarta Timur. Sampel penelitian sebanyak 88 responden diambil dengan menggunakan teknik Random Sampling. Teknik analisis data yang digunakan adalah teknik analisis data secara deskriptif dan inferensial.

\section{HASIL DAN PEMBAHASAN}

\section{Pengaruh reward terhadap komitmen organisasi}

Berdasarkan hasil pengujian hipotesis pertama dalam penelitian ini diterima. Hipotesis pertama adalah reward berpengaruh langsung positif terhadap komitmen organisasi. Koefisien jalur yang diperoleh adalah 0,427 dengan koefisien korelasi 0,594. Kenyataan empiris ini sejalan dengan pendapat dan temuan yang dikemukakan oleh James L. Gibson et al (2006:190) "if effectively used, rewards can affect such individual behaviors as turnover, absenteeism, performance, and commitment." Apabila digunakan 
secara efektif, penghargaan akan berefek kepada perilaku perseorangan sebagai titik balik, tingkat kehadiran, kinerja dan komitmennya.

Namun sebaliknya, apabila pemberian penghargaan ini dibaikan maka, akan berdampak pada rendahnya tingkat kehadiran, indispliner, rendahnya etos kerja minimnya loyalitas seseorang terhadap organisasi. Kepala madrasah akan tetap bertahan dalam sebuah lembaga pendidikan (madrasah) manakala pemberian reward oleh yayasan dilakukan secara konsisten. Hal ini didukung oleh hasil responden di lapangan yang sebagian besar mereka menjawab pilihan (option) 1 (sangat tidak sesuai) dan 2 (tidak sesuai) apabila pernyataannya seputar kenaikan gaji, pemberian bonus dan pemberian tunjangan.

Kebanyakan lembaga pendidikan dalam hal ini madrasah yang notabene swasta mengalami permasalahan yang sama. Sama dalam artian pemberian reward yang masih terbilang rendah, baik kemampuan keuangan maupun sistem yang dikembangkan. Sebagaimana Angelo kinicki and Robert Kreither (2008:210) yang menjelaskan, "good reward system should attract talented people and motivate and satisfy them once they have joined the organization." Sistem penghargaan yang baik dapat menarik orang-orang yang berbakat, bermotivasi dan memuaskan mereka, saat mereka sudah bergabung dalam organisasi. Besaran nilai penghargaan yang diberikan sangat relatif, tidak dapat ditentukan jumlahnya. Hal ini dikarenakan kebutuhan manusia berbeda-beda dan tidak terbatas. Kendati demikian yang terpenting bagaimana membangun sistem pemberian penghargaan secara transparan dan proporsional tentunya dengan tidak mengabaikan kemampuan yayasan. Apabila sistem sudah dijalankan dengan baik, maka akan berdampak baik pula komitmen seorang kepala madrasah terhadap satuan pendidikan yang dipimpinnya.

\section{Pengaruh kepuasan kerja terhadap komitmen organisasi}

Diterimanya hipotesis kedua dalam penelitian ini merupakan temuan berikutnya. Hipotesis kedua yang dimaksudkan adalah kepuasan kerja berpengaruh terhadap komitmen organisasi. Koefisien jalur yang diperoleh adalah 0,311 dengan koefisien korelasi 0,540. Hasil pengujian tersebut sejalan dengan pendapat Debra L. Nelson (2006:125) yang menyatakan, "job satisfaction and organizational commitment are two important work attitudes that managers can strive to improve among their employees. And these two attitudes are strongly related. Both affective and normative commitment are related to job satisfaction."

Kepuasan bekerja dan komitmen dalam berorganisasi adalah dua sikap penting dari pekerja yang dapat dikembangkan oleh manager (pimpinan) di antara pekerjanya. Dan kedua sikap ini sangat berkaitan erat. Baik komitmen afektif maupun komitmen normatif sangat berhubungan erat dengan kepuasan dalam kerja. Komitmen afektif berkaitan dengan keyakinan yang kuat dari kepala madrasah terhadap madrasah yang dipimpinnya dengan segala kelebihan dan kekurangannya. Sedangkan komitmen normatif berkaitan dengan konsistensi dari kepala madrasah dalam menjalankan tugas pokok dan fungsinya sebagai kepala madrasah. Juga konsisten terhadap norma/aturan yang telah ada dan yang disepakati bersama.

Selain itu, Jennifer M George (2005:93) juga mengatakan, "whereas job satisfaction relates to feelings and beliefs that individuals have about specific jobs, organizational commitment relates to feelings and belief about the employing organization as a whole." Sebagaimana kepuasan kerja berhubungan dengan perasaan dan keyakinan yang dianut oleh individu untuk suatu pekerjaan yang spesifik, komitmen organisasi berhubungan dengan perasaan dan keyakinan tentang tempat mereka bekerja secara keseluruhan. 
Hal ini senada dengan pendapatnya Fred Luthans (2008:147) yang menyatakan, "whereas satisfaction is mainly concerned with the employee's attitude toward the job and commitment is at the level of the organization, a strong relationship between job satisfaction and organizational commitment has been found over the years." Kepuasan adalah hal penting yang harus diperhatikan, dengan sikap pekerja terhadap pekerjaan dan komitmen pada tingkatan organisasi, hubungan yang kuat antara kepuasan kerja dan komitmen organisasi telah ditemukan selama bertahun-tahuan.

Kepuasan kepala madrasah akan tercipta jika situasi kerja aman dan nyaman, di mana perasaan puas seorang kepala madrasah dapat menumbuhkan keyakinan terhadap organisasi dalam hal ini lembaga pendidikan yang dipimpinnya. Sehingga hal ini tidak mudah bagi kepala madrasah untuk meninggalkannya.

\section{Pengaruh reward terhadap kepuasan kerja}

Dari hasil pengujian hipotesis yang ketiga yakni reward berpengaruh terhadap kepuasan kerja yang memperoleh koefisien jalur sebesar 0,537 dengan koefisien korelasi 0,537 . Hasil pengujian tersebut sejalan dengan pendapat bebarapa tokoh, salah satunya adalah John R. Schermerhorn (2010:335), "one of the more popular positions is that job performance followed by reward that are valued and perceived as fair will create job satisfaction." Salah satu dari beberapa posisi yang diminati, adalah kinerja pekerjaan akan diikuti dengan reward yang telah diberikan penilaian dan dipersepsikan sebagai hal yang wajar akan menciptakan kepuasan dalam bekerja. Pendapat ini dapat dipersempit bahwa apabila yayasan dalam memberikan penghargaan sesuai maka, kepuasan kerja kepala madrasah akan tercipta dengan sendirinya.

Selain itu, James L. Gibson at al (2006:190) menjelaskan, "an individual's satisfaction with a reward is influenced by: how much is received and how much the person feels should be received; comparisons with what happens to others; how satisfied the person is with both intrinsic and extrinsic rewards; the relative importance of different rewards, and whether the reward leads to other rewards." Sebuah kepuasan individual dengan penghargaan dipengaruhi oleh: berapa besar ia diterima dan berapa besar perasaan seseorang dapat menerimanya; dibandingkan dengan yang terjadi pada yang lain; berapa besar tingkat kepuasan seseorang ditinjau dari penghargaan intrinsik dan ekstrinsiknya; besarnya hubungan kepentingan dari beberapa penghargaan yang berbeda, dan apakah penghargaan itu akan mengarah kepada penghargaan berikutnya.

Keseimbangan antara reward dan kinerja mempengaruhi kepuasan kerja seorang kepala madrasah dalam menjalankan tanggungjawabnya. Tidak sedikit yayasan yang mengabaikan hal ini, sehingga di lapangan terjadi kesenjangan. Sebagaimana Debra L. Nelson (2006:123) menyatakan, "another reason for the lack of a clear relationship between satisfaction and performance is the intervening role of rewards. Employees who receive valued rewards are more satisfied." Alasan lain atas kesenjangan dari kejelasan hubungan antara kepuasan dan kinerja adalah dengan intervensi peran dari reward (penghargaan). Pekerja yang menerima nilai-nilai dari reward akan terpuaskan.

Debra juga menambahkan bahwa, "rewards thus influence both satisfaction and performance. The key to influencing both satisfaction and performance through rewards is that the rewards are valued by employees and are tied directly to performance." Reward juga berpengaruh pada kepuasan dan kinerja. Kunci yg mempengaruhi keduanya melalui reward (penghargaan) adalah bentuk penghargaan yang diberikan pekerja dan sangat berhubungan dengan kinerja mereka. Untuk menciptakan kepuasan kerja seorang kepala madrasah tentunya tidak terlepas dari reward yang diterimanya.

\section{PENUTUP}


Kesimpulan. Berdasarkan analisis terhadap hasil penelitian dapat disampaikan beberapa temuan penelitian sebagai berikut: (1) Terdapat pengaruh Iangsung positif reward terhadap komitmen organisasi kepala madrasah ibtidaiyah swasta di Jakarta Timur. (2) Terdapat pengaruh langsung positif kepuasan kerja terhadap komitmen organisasi kepala madrasah ibtidaiyah swasta di Jakarta Timur. (3) Terdapat pengaruh langsung positif reward terhadap kepuasan kerja kepala madrasah ibtidaiyah swasta di Jakarta Timur.

Saran. Pertama, bagi para pengambil keputusan (yayasan) hendaknya memperhatikan masalah reward dan kepuasan kerja kepala madrasah dalam rangka meningkatkan komitmen organisasi kepala madrasah. Selain itu, ternyata masih banyak variabel lain yang berpengaruh langsung terhadap komitmen kepala madrasah. Pemahaman tentang komitmen organisasi kepala madrasah akan membantu para pengambil keputusan (yayasan) dalam mewujudkan tujuan organisasi bersama-sama dengan kepala madrasah.

Kedua, bagi para kepala madrasah ibtidaiyah swasta di Jakarta Timur hendaklah terus berupaya meningkatkan loyalitas terhadap satuan pendidikan masing-masing. Dengan tetap menjalankan tugas pokok dan fungsi (tupoksi) sebagai kepala madrasah dengan penuh rasa tanggungjawab. Hal ini dimaksudkan untuk mencapai cita-cita bangsa Indonesia yakni mencerdaskan kehidupan bangsa dan mewujudkan visi dan misi madrasah masing-masing. 


\section{DAFTAR RUJUKAN}

Andre, Rae. Organizational Behavior An Introduction to your life in Organizations. Singapore: Pearson Prentice Hall, 2008.

Daft, Richard L. New Era of Management. South-Western: Cengage Learning, 2010.

Dessler, Gary. Management leading people and organizations in the 21 st century. London: Prentice Hall, 2001.

Gibson, James L., et al. Organizations behavior structure processes. Boston: McGraw-Hill, 2006.

Griffin, Ricky W. and Gregory. Organizational Behavior Managing people and Organizations. Boston New York: Houghton, 2007.

George, Jennifer M. and Gareth R. Jones Understanding and Managing Organizational Behavior. Singapore: Pearson Prentice Hall, 2005.

Kinicki, Angelo and Robert Kreither. Organizational Behavior Key Concepts, Skills E Best Practices. Boston : McGraw-Hill/Irwin 2008.

Luthans, Fred. Organizational Behavior. Singapore: McGraw-Hill, 2008.

Mulyasa. Menjadi Kepala Sekolah Profesional. Bandung: Remaja Rosdakarya, 2004.

Nelson, Debra L. James Campbell Quick. Organizational Behavior Foundations, Realities $\mathcal{E}$ Challenges. Australia: Thomson, 2006.

Robbins, Stephen P. and Timothy A. Judge. Organizational Behavior Fourteenth Edition. Boston: Pearson, 2011.

Schermerhorn, John R. Introduction to management. Asia: John Wiley \& Sons, Inc. 2010. 